\title{
Pengaruh Minat Baca Dan Kontinuitas Belajar Terhadap Hasil Belajar Ski Pada Siswa MTs. DDI Cabang Mapilli Kecamatan Mapilli Kabupaten Polewali Mandar
}

\author{
Mahfud Hannan \\ Fakultas Tarbiyah dan Ilmu Keguruan \\ Institut Agama Islam DDI Polewali Mandar \\ Jl. Gatot Soebroto Kelurahan Madatte Kecamatan Polewali Kab. Polewali Mandar
}

\begin{abstract}
ABSTRAK
Penelitian ini bertujuan untuk mengetahui minat baca dan kontinuitas belajar Sejarah Kebudayaan Islam dan pengaruhnya terhadap hasil belajar Sejarah Kebudayaan Islam pada siswa MTs. DDI Cabang Mapilli Kecamatan Mapilli Kabupaten Polewali Mandar. Jenis penelitian ini adalah explanatory research dengan pendekatan penelitian kuantitatif. Adapun yang menjadi populasi penelitian dalam penelitian ini adalah siswa kelas VIII MTs. DDI Cabang Mapilli Kecamatan Mapilli Kabupaten Polewali Mandar dengan jumlah sampel 24 orang siswa. Tekhnik pengumpulan data yang digunakan adalah observasi, angket (kuesioner), dan dokumentasi. Data-data yang telah dikumpulkan selanjutnya dianalisis secara statistik deskriptif dan teknik analisis statistik inferensial berupa uji normalitas dan analisis regresi linier berganda.

Hasil penelitian menunjukkan bahwa Minat baca yang dimiliki siswa kelas VIII MTs. DDI Cabang Mapilli Kecamatan Mapilli Kabupaten Polewali Mandar adalah tergolong rendah dengan nilai rata-rata (mean) sebesar 21,75 yang dapat dilihat dari kurangnya aktifitas membaca yang dilakukan siswa baik di dalam kelas ataupun juga di luar kelas. Kontinuitas belajar Sejarah Kebudayaan Islam pada siswa kelas VIII MTs. DDI Cabang Mapilli Kecamatan Mapilli Kabupaten Polewali Mandar sudah terlaksana dengan baik dengan nilai rata-rata (mean) sebesar 23,25 dimana aktifitas belajar siswa terlihat lebih tekun belajar baik secara individu maupun kelompok dan dalam aktifitas pembelajaran di kelas, semua siswa dapat mengikuti kegiatan pembelajaran dengan baik. Ada pengaruh yang signifikan dari minat baca dan kontinuitas belajar terhadap hasil belajar Sejarah Kebudayaan Islam yang diperoleh siswa kelas VIII MTs. DDI Cabang Mapilli Kecamatan Mapilli Kabupaten Polewali Mandar. Variabel minat baca (X1) dan kontinuitas belajar (X2) secara bersamasama hanya berpengaruh sebesar 36,4\% terhadap variabel hasil belajar Sejarah Kebudayaan Islam siswa (Y). Sedangkan sisanya sebesar 63,6\% dipengaruhi oleh variabel-variabel lain yang tidak dikaji dalam penelitian ini.
\end{abstract}

Kata Kunci: Minat Baca, Kontinuitas Belajar, dan Hasil Belajar Sejarah Kebudayaan Islam

\section{PENDAHULUAN}

\section{A. Latar Belakang Masalah}

Setiap warga negara mempunyai hak yang sama untuk memperoleh pendidikan serta kesempatan seluas-luasnya untuk mengikuti pendidikan agar memperoleh pengetahuan, kemampuan 
dan keterampilan yang sekurang-kurangnya setara dengan tamatan pendidikan dasar. ${ }^{1}$ Merujuk dari definisi tersebut, secara yuridis pendidikan memiliki peranan yang sangat penting dalam kehidupan suatu bangsa. Pendidikan dapat mempengaruhi perkembangan suatu bangsa dalam seluruh aspek kehidupan kebangsaan. Pendidikan dapat mengembangkan berbagai potensi yang dimiliki warga negara secara optimal. Pendidikan merupakan kegiatan sekelompok orang atau lembaga dalam membantu individu ataupun juga sekelompok orang untuk mencapai tujuan pendidikan. Pendidikan memiliki pengaruh yang dinamis terhadap kelanggengan suatu bangsa di masa depan.

Pada hakikatnya, pendidikan berlangsung seumur hidup (long life education) dan merupakan tanggung jawab bersama antara keluarga, masyarakat, dan pemerintah. Oleh karena itu, pemerintah Indonesia mencanangkan program wajib belajar pendidikan dasar sembilan tahun untuk meratakan kesempatan pendidikan bagi seluruh warga negara Indonesia. Berdasarkan Peraturan Pemerintah Republik Indonesia nomor 47 tahun 2008 tentang Wajib Belajar, dijelaskan bahwa wajib belajar adalah program pendidikan minimal yang harus diikuti oleh warga negara Indonesia atas tanggung jawab pemerintah dan pemerintah daerah. ${ }^{2}$ Pendidikan minimal yang dimaksud yaitu dari tingkat SD dan sederajat sampai SMP dan sederajat atau selama sembilan tahun.

Secara teoritis, pendidikan dimaksudkan agar membawa perubahan bagi siswa, dari tidak bisa membaca menjadi bisa membaca, dari tidak bisa berhitung menjadi bisa berhitung, dari tidak bisa menulis menjadi bisa menulis dan sebagainya. Perubahan semacam ini tentu saja sangat penting bagi siswa dalam proses pendidikan. Ada tiga lingkungan penting yang sangat berpengaruh, yaitu lingkungan keluarga, sekolah dan masyarakat.

Proses pendidikan di sekolah dasar dan sekolah menengah pertama perlu lebih memperhatikan tingkat perkembangan kognitif dan juga afektif siswa, sehingga pendidikan yang diberikan kepada siswa menjadi lebih bermakna serta perlu untuk lebih ditekankan pada upaya agar siswa mampu dan mau belajar berdasarkan kebermaknaan belajarnya. ${ }^{3}$

Madrasah Tsanawiyah (MTs) merupakan sekolah menengah pertama yang termasuk bagian dari program wajib belajar sembilan tahun, dan merupakan lembaga pendidikan yang menekankan siswa untuk belajar membaca, menulis, dan berhitung. Keterampilan tersebut merupakan landasan dan syarat bagi siswa untuk memperoleh ilmu pengetahuan. Tanpa penguasaan keterampilan, siswa akan mengalami kesulitan untuk menguasai ilmu pengetahuan. Selain penguasaan keterampilan tersebut, hal yang paling mendasar untuk menguasai sebuah ilmu pengetahuan adalah dengan menguasai bahasa.

Menurut BSNP, bahasa memiliki peran sentral dalam perkembangan intelektual, sosial, dan emosional siswa dan merupakan penunjang keberhasilan dalam mempelajari semua bidang studi. Pembelajaran bahasa diharapkan membantu siswa mengenal dirinya, budayanya, dan budaya orang lain, mengemukakan gagasan dan perasaan, berpartisipasi dalam masyarakat yang menggunakan

\footnotetext{
${ }^{1}$ Hera Lestari Mikarsa, Pendidikan Anak di SD dan SMP, Cetakan ke XV (Jakarta: Universitas Terbuka, 2013), h. 10.5 .

${ }^{2}$ Republik Indonesia, Peraturan Pemerintah Republik Indonesia No. 47 Tahun 2008 tentang Wajib Belajar (Jakarta: Pemerintah RI, 2008).

${ }^{3}$ Hera Lestari Mikarsa, Pendidikan Anak di SD dan SMP, h. 1.20.
} 
bahasa tersebut, dan menemukan serta menggunakan kemampuan analitis dan imaginatif yang ada dalam dirinya. ${ }^{4}$

Farr dalam Dalman mengemukakan, "reading is the heart of education", yang artinya membaca merupakan jantung pendidikan. ${ }^{5}$ Hal tersebut menjelaskan bahwa membaca merupakan faktor penting dalam sebuah proses pembelajaran di sekolah. Membaca juga merupakan salah satu pintu utama untuk dapat mengakses pengetahuan dan informasi.

Menurut pakar neurologi (ilmu sains media tentang otak), membaca merupakan sebuah proses yang kompleks, melibatkan segenap panca indera, serta merangsang aktifnya sel-sel otak, dan dendrit yang terus membuat simpul baru pada otak seiring berjalannya proses membaca. ${ }^{6}$ Hodgson dalam Tarigan menyebutkan bahwa membaca adalah proses yang dilakukan serta dipergunakan oleh pembaca untuk memperoleh pesan yang hendak disampaikan oleh penulis melalui media kata-kata atau bahasa tulis. Jadi dengan membaca, siswa dapat memperoleh pengetahuan yang disediakan penulis. Semakin sering seorang siswa membaca, maka pengetahuan dan wawasan yang dimilikinya akan semakin luas. Hal ini dapat mempengaruhi proses belajar dan pola pikir siswa yang bersangkutan. ${ }^{7}$

Slameto menjelaskan bahwa belajar ialah suatu proses usaha yang dilakukan seseorang untuk memperoleh suatu perubahan tingkah laku yang baru secara keseluruhan, sebagai hasil pengalamannya sendiri dalam interaksi dengan lingkungannya. Jadi, belajar adalah proses perubahan individu secara komprehensif sebagai hasil interaksi dengan lingkungan dan pengalamannya. Kebiasaan yang dilakukan individu selama proses pembelajaran akan berpengaruh terhadap hasil belajar yang diperolehnya. Salah satu kebiasaan baik yang paling banyak dilakukan selama belajar adalah kegiatan membaca. ${ }^{8}$

Kebiasaan membaca yang dilakukan oleh seseorang ditentukan oleh berbagai faktor, salah satunya minat. Hilgard dalam Slameto menyebutkan bahwa minat adalah kecenderungan untuk menaruh perhatian dan menikmati beberapa kegiatan. Minat merupakan faktor internal yang mempengaruhi seseorang untuk berbuat sesuatu, salah satunya membaca. Orang yang memiliki minat dalam kegiatan membaca akan cenderung menyukai dan menaruh perhatiannya pada kegiatan tersebut. ${ }^{9}$

Menurut Lilawati dalam Sudarsana dan Bastiano, minat baca adalah suatu perhatian yang kuat dan mendalam disertai dengan perasaan senang terhadap kegiatan membaca sehingga mengarahkan individu untuk membaca dengan kemauannya sendiri. Minat baca merupakan salah satu kunci penting bagi seseorang untuk memperoleh ilmu pengetahuan dan informasi. ${ }^{10}$

Dewasa ini, minat membaca yang dimiliki siswa tingkat sekolah menengah pertama (SMP/MTs) masih terasa kurang optimal. Hal ini dapat diamati dari kurangnya aktifitas membaca yang dilakukan siswa baik di rumah ataupun juga di sekolah. Ruang perpustakaan yang ada di sekolah

\footnotetext{
${ }^{4}$ BSNP, Standar Isi untuk Satuan Pendidikan Dasar dan Menengah (Jakarta: BSNP, 2006), h. 119.

${ }^{5}$ Dalman, Keterampilan Membaca (Jakarta: Rajawali Pers, 2014), h. 5 .

${ }^{6}$ Bob Harjanto, Merangsang dan Melejitkan Minat Baca Anak Anda (Yogyakarta: Manika Books, 2011), h. 7.

${ }^{7}$ Henry Guntur Tarigan, Membaca sebagai Suatu Keterampilan Berbahasa (Bandung: Angkasa, 2015), h. 7.

${ }^{8}$ Slameto, Belajar dan Faktor-faktor yang Mempengaruhinya (Jakarta: Rineka Cipta, 2013), h. 2.

${ }^{9}$ Slameto, Belajar dan Faktor-faktor yang Mempengaruhinya, h. 57.

${ }^{10}$ Undang Sudarsana dan Bastiano, Pembinaan Minat Baca (Jakarta: Universitas Terbuka, 2012), h. 4.27.
} 
tidak dimanfaatkan sebagaimana mestinya oleh siswa. Setelah dilakukan observasi di sekolah, ruang perpustakaan yang ada sangat jarang dikunjungi siswa. Siswa masih enggan untuk membaca buku di perpustakaan sekolah. Siswa baru membaca atau meminjam buku jika diberikan tugas oleh gurunya. Di rumah, siswa pun lebih tertarik untuk membaca novel ataupun komik.

Tidak tersedianya buku-buku yang menarik bagi siswa, penataan yang kurang teratur dan sistematis, turut mendukung kurangnya minat dan aktifitas membaca siswa tingkat sekolah menengah pertama (SMP/MTs). Hal ini dikarenakan tenaga pengelola perpustakaan kurang memiliki kompetensi sebagai pengelola perpustakaan. Petugas perpustakaan hanya pekerjaan tambahan guru dan ada pula yang diserahkan pada guru wiyata bakti, sehingga layanan perpustakaan tingkat sekolah menengah pertama (SMP/MTs) tidak optimal.

Suherman dalam Naim menyebutkan setidaknya ada tiga faktor yang menjadi penyebab rendahya minat baca. Pertama, kondisi warisan dari orang tua yang disebut determinisme genetis. Kedua, seseorang tidak senang membaca karena memang sejak kecil dibesarkan oleh orang tua yang tidak pernah mendekatkan dirinya dengan bacaan yang disebut determinisme psikis. Ketiga, determinisme lingkungan pada dasarnya mengatakan bahwa seseorang tidak senang membaca karena atasan atau bawahan, teman, guru atau dosen tidak senang membaca. Selain itu, di rumah, kantor, dan sekolah tidak disediakan perpustakaan serta tidak ada peraturan yang mengharuskan untuk membaca. situasi ekonomi yang kurang mendukung dan tidak adanya kebijakan nasional tentang minat membaca menjadikan membaca menjadi suatu hal yang sulit ditumbuh kembangkan. ${ }^{11}$

Dampak dari kurangnya minat membaca siswa juga diikuti oleh kurangnya kontinuitas belajar siswa. Kontinuitas belajar siswa pun terasa masih sangat kurang memadai. Hal ini bisa dipahami karena sebagian besar aktifitas belajar siswa adalah melalui membaca. Dapat dikatakan siswa lebih banyak bermain dari pada belajar. Siswa juga lebih sering bermain play station ataupun juga menonton televisi. Faktor dukungan dari keluarga, baik dukungan secara psikologis maupun kelengkapan belajar, sering menjadi alasan bagi siswa tidak merasa nyaman dalam melakukan kegiatan belajar di rumah. Akibat dari tidak adanya kontinuitas siswa dalam belajar menyebabkan aktifitas belajar yang dilakukan siswa menjadi tidak teratur. Tidak teraturnya aktifitas belajar menyebabkan tidak optimalnya penguasaan materi yang dikuasai siswa. Akibat dari hal-hal tersebut, hasil belajar yang diperoleh siswa juga kurang maksimal.

Mengacu pada hal-hal yang telah dikemukakan tersebut, penulis merasa ada suatu ketidaksesuaian antara teori dengan kenyataan yang terjadi di MTs. DDI Cabang Mapilli. Hasil belajar yang diraih siswa MTs. DDI Cabang Mapilli bisa dikatakan bagus, seperti hasil belajar Sejarah Kebudayaan Islam yang diraih siswa kelas VIII MTs. DDI Cabang Mapilli menunjukkan bahwa $86,6 \%$ siswa mendapat nilai di atas KKM $(\mathrm{KKM}=75)$, sedangkan 13,4\% lainnya masih mendapatkan nilai di bawah KKM yang telah ditentukan. Namun dengan melihat perpustakaan sekolah yang sepi pengunjung menimbulkan pertanyaan apakah siswa kelas VIII MTs. DDI Cabang Mapilli memiliki minat untuk membaca? Apakah dalam kesehariannya di rumah, siswa memiliki minat untuk membaca? Berkaitan dengan hal tersebut, penulis juga ingin mengetahui bagaimana aktifitas belajar siswa di rumah yang berkaitan dengan kontinuitas belajarnya.

\footnotetext{
${ }^{11}$ Ngainun Naim, The Power of Reading (Yogyakarta: Aura Pustaka, 2013), h. 10.
} 
Berdasarkan hal-hal tersebut, penulis memandang penelitian ini sangat penting artinya sebagai salah satu usaha untuk memberikan sumbangan pemikiran yang baik bagi dunia pendidikan, khususnya di MTs. DDI Cabang Mapilli Kecamatan Mapilli. Untuk itu, perlu diadakan sebuah kajian secara sistematis dan ilmiah tentang hal-hal yang telah disebutkan sebelumnya dalam bentuk penelitian ilmiah dengan judul "Pengaruh Minat Baca Dan Kontinuitas Belajar Terhadap Hasil Belajar Sejarah Kebudayaan Islam Pada Siswa MTs. DDI Cabang Mapilli Kecamatan Mapilli Kabupaten Polewali Mandar".

\section{B. Rumusan Masalah}

Berdasarkan latar belakang masalah yang telah dipaparkan sebelumnya maka dapat dirumuskan masalah sebagai berikut:

1. Bagaimankah minat baca siswa kelas VIII MTs. DDI Cabang Mapilli Kecamatan Mapilli Kabupaten Polewali Mandar?

2. Bagaimankah kontinuitas belajar Sejarah Kebudayaan Islam pada siswa kelas VIII MTs. DDI Cabang Mapilli Kecamatan Mapilli Kabupaten Polewali Mandar?

3. Apakah ada pengaruh minat baca dan kontinuitas belajar terhadap hasil belajar Sejarah Kebudayaan Islam pada siswa kelas VIII MTs. DDI Cabang Mapilli Kecamatan Mapilli Kabupaten Polewali Mandar?

\section{Hipotesis Penelitian}

Adapun hipotesis yang dapat dirumuskan dalam penelitian ini adalah: "Ada pengaruh minat baca dan kontinuitas belajar yang positif dan signifikan terhadap hasil belajar Sejarah Kebudayaan Islam pada siswa kelas VIII MTs. DDI Cabang Mapilli Kecamatan Mapilli Kabupaten Polewali Mandar".

\section{Tujuan Penelitian}

Sejalan dengan rumusan masalah yang telah dikemukakan, maka tujuan penelitian ini adalah:

1. Untuk mengetahui minat baca yang dimiliki siswa kelas VIII MTs. DDI Cabang Mapilli Kecamatan Mapilli Kabupaten Polewali Mandar.

2. Untuk mengetahui kontinuitas belajar Sejarah Kebudayaan Islam pada siswa kelas VIII MTs. DDI Cabang Mapilli Kecamatan Mapilli Kabupaten Polewali Mandar.

3. Untuk mengetahui ada tidaknya pengaruh minat baca dan kontinuitas belajar terhadap hasil belajar Sejarah Kebudayaan Islam pada siswa kelas VIII MTs. DDI Cabang Mapilli Kecamatan Mapilli Kabupaten Polewali Mandar.

\section{E. Manfaat Penelitian}

1. Hasil penelitian ini dapat menjadi sumbangan pemikiran bagi perkembangan ilmu pengetahuan pada umumnya dan dalam ilmu pendidikan pada khususnya.

2. Hasil penelitian ini diharapkan dapat menambah pengetahuan siswa tentang manfaat membaca dan kontinuitas belajar, sehingga siswa dapat meningkatkan motivasi dan minat bacanya serta dapat meningkatkan kontinuitas belajar dan hasil belajarnya. 
3. Hasil penelitian ini diharapkan dapat membantu guru untuk memahami pentingnya membaca dan kontinuitas belajar serta pengaruhnya terhadap hasil belajar siswa, sehingga guru dapat menumbuh kembangkan minat siswa untuk membaca dan dapat meningkatkan kontinuitas dan hasil belajar siswanya.

4. Sekolah diharapkan dapat menghasilkan lulusan-lulusan yang berkualitas dan juga sebagai bahan kajian untuk menentukan kebijakan dalam pelaksanaan pembelajaran di sekolah, serta memberikan kontribusi positif bagi sekolah dalam rangka pencapaian tujuan pendidikan sekolah pada khususnya dan tujuan pendidikan nasional pada umumnya.

\section{METODE PENELITIAN}

Berdasarkan tujuan yang hendak dicapai maka penelitian ini termasuk jenis atau tipe penelitian explanatory research, yaitu jenis penelitian yang bertujuan untuk mengetahui hubungan pengaruh antara dua buah variabel atau lebih. ${ }^{12}$ Pendekatan yang digunakan dalam penelitian ini adalah pendekatan kuantitatif. Penelitian explanatory research dengan pendekatan penelitian kuantitatif digunakan untuk mengetahui dan memperoleh data atau informasi yang akurat tentang pengaruh minat baca dan kontinuitas belajar terhadap hasil belajar Sejarah Kebudayaan Islam pada siswa kelas VIII MTs. DDI Cabang Mapilli Kecamatan Mapilli Kabupaten Polewali Mandar.

Penelitian ini dilaksanakan di kelas VIII MTs. DDI Cabang Mapilli Kecamatan Mapilli Kabupaten Polewali Mandar pada tahun pelajaran 2019/2020 dan penelitian ini dilaksanakan bulan Agustus 2019 sampai dengan Oktober 2019. Populasi dalam penelitian ini adalah seluruh siswa kelas VIII MTs. DDI Cabang Mapilli Kecamatan Mapilli Kabupaten Polewali Mandar yang berjumlah 24 orang siswa. Teknik pengambilan sampel yang digunakan adalah total sampling, yaitu pengambilan sampel secara penuh dimana seluruh anggota populasi diambil untuk dijadikan sampel penelitian, sehingga penelitian ini menjadi penelitian populasi.

Variabel bebas dalam penelitian ini adalah minat baca $\left(\mathrm{X}_{1}\right)$ dan kontinuitas belajar $\left(\mathrm{X}_{2}\right)$. Sedangkan variabel terikatnya adalah hasil belajar Sejarah Kebudayaan Islam (Y). Hubungan antar variabel dalam penelitian ini dapat digambarkan berikut:

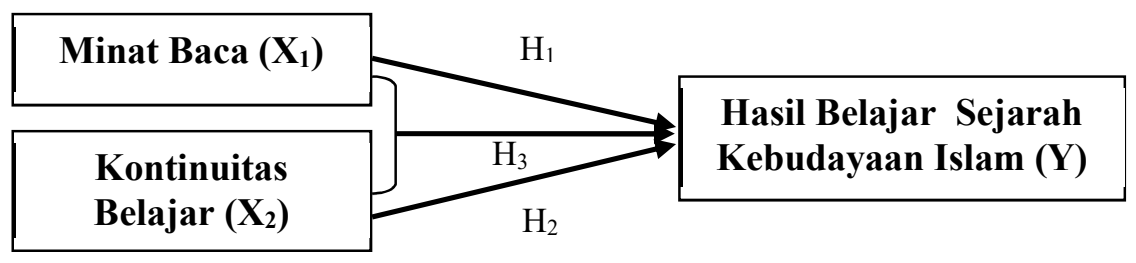

Gambar 1. Hubungan antar Variabel Penelitian

Terdapat dua hal utama yang mempengaruhi kualitas data hasil penelitian, yaitu kualitas instrumen penelitian dan kualitas pengumpulan data. Kualitas instrumen penelitian berkenaan dengan validitas dan reabilitas instrument. Kualitas pengumpulan data berkenaan dengan ketepatan cara-cara

\footnotetext{
${ }^{12}$ Syofian P. Siregar, Statistik Deskriptif Untuk Penelitian (Jakarta: PT. Raja Grafindo Persada, 2010), h. 107.
} 
yang digunakan untuk mengumpulkan data. ${ }^{13}$ Dari segi cara atau teknik pengumpulan data, maka teknik pengumpulan data pada penelitian ini adalah melalui observasi, angket (kuesioner), dan dokumentasi.

Jenis observasi yang digunakan dalam penelitian ini adalah observasi non partisipan. Hal yang diamati adalah aktifitas membaca siswa di dalam kelas dan di perpustakaan sekolah. Penggunaan angket/kuesioner dalam penelitian ini untuk memperoleh data atau untuk mengungkap indikator-indikator minat baca dan kontinuitas belajar siswa. Angket yang digunakan berupa angket tertutup yang disajikan dalam bentuk pernyataan menggunakan skala Likert dengan 4 alternatif pilihan jawaban. Responden (siswa) diminta untuk memilih 1 kategori jawaban dari 4 alternatif jawaban yang tersedia. Skor untuk setiap butir soal ditampilakan pada tebel berikut:

Tabel 1.

Skor untuk Butir pada Skala Likert ${ }^{14}$

\begin{tabular}{|c|c|c|}
\hline Jawaban & $\begin{array}{c}\text { Skor Pernyataan } \\
\text { Positif }\end{array}$ & $\begin{array}{c}\text { Skor Pernyataan } \\
\text { Negatif }\end{array}$ \\
\hline Sangat Setuju & 4 & 1 \\
\hline Setuju & 3 & 2 \\
\hline Tidak Setuju & 2 & 3 \\
\hline Sangat Tidak Setuju & 1 & 4 \\
\hline
\end{tabular}

Teknik analisis data yang digunakan dalam penelitian ini adalah teknik analisis statistik deskriptif dan teknik analisis statistik inferensial berupa uji normalitas dan analisis regresi linier berganda. Analisis statistik deskriptif dalam penelitian ini digunakan untuk mengetahui gambaran umum mengenai minat baca sebagai variabel bebas $\left(\mathrm{X}_{1}\right)$, kontinuitas belajar sebagai variabel bebas $\left(\mathrm{X}_{2}\right)$, dan hasil belajar Sejarah Kebudayaan Islam sebagai variabel terikat (Y) yang diperoleh siswa kelas VIII MTs. DDI Cabang Mapilli Kecamatan Mapilli Kabupaten Polewali Mandar.

Uji normalitas digunakan untuk mengetahui bahwa data-data penelitian yang diperoleh dari suatu sampel adalah berdistribusi normal atau tidak. Uji normalitas suatu data sampel merupakan prasyarat untuk analisis inferensial selanjutnya, seperti untuk analisis perbandingan atau perbedaan dua kolompok data, analisis hubungan antara dua varibel atau lebih dan analisis pengaruh satu varibel bebas atau lebih terhadap varibel terikat. ${ }^{15}$

Analisis regresi linear berganda digunakan untuk uji hipotesis. Analisis regresi pada dasarnya adalah studi mengenai ketergantungan variabel dependen (terikat) dengan satu atau lebih variabel independen (bebas), dengan tujuan untuk mengestimasi dan atau memprediksi rata-rata populasi atau nilai rata-rata variabel dependen berdasarkan nilai variabel independen yang diketahui. ${ }^{16}$ Uji-t digunakan untuk menguji bahwa variabel independent (bebas) mempunyai pengaruh secara parsial dan signifikan terhadap variabel dependent (terikat) atau tidak. Kaidah pengambilan keputusan dalam uji t dengan menggunakan komputer program SPSS versi 20.0 for windows dengan tingkat signifikasi $5 \%$.

\footnotetext{
${ }^{13}$ Sugiyono, Metode Penelitian Pendekatan Kuantitatif, Kualitatif, dan R \& D (Bandung: Alfabeta, 2015), h. 193.

${ }^{14}$ Sugiyono, Metode Penelitian Pendekatan Kuantitatif, Kualitatif, dan R \& D, h. 135.

${ }^{15}$ Yusri, Statistika Sosial : Aplikasi dan Interpretasi (Yogyakarta: Graha Ilmu, 2009), h. 147

${ }^{16}$ Imam Ghozali, Aplikasi Analisis Multivariate dengan Program SPSS (Semarang: B-P UNDIP, 2011), h. 85.
} 
Uji F digunakan untuk menentukan pengaruh variabel independent (bebas) secara bersamasama atau simultan dan signifikan terhadap variabel dependent (terikat). Kaidah pengambilan keputusan dalam uji $\mathrm{F}$ adalah: "Bila nilai $F_{\text {hitung }}$ lebih besar dari $F_{\text {tabel, }}$ maka Ho ditolak dan Ha diterima, artinya terdapat pengaruh secara simultan yang signifikan antara variabel bebas terhadap variabel terikat. Uji Koefisien Determinasi $\left(\mathrm{R}^{2}\right)$ untuk mengetahui besarnya pengaruh variabel bebas terhadap variabel tidak bebas (terikat). Nilai koefisien determinasi $\left(\mathrm{R}^{2}\right)$ dapat ditentukan dengan melihat hasil output SPSS.

\section{HASIL PENELITIAN DAN PEMBAHASAN}

\section{A. Deskripsi Data Hasil Penelitian}

Penelitian yang berjudul "Pengaruh Minat Baca Dan Kontinuitas Belajar Terhadap Hasil Belajar Sejarah Kebudayaan Islam Pada Siswa MTs. DDI Cabang Mapilli Kecamatan Mapilli Kabupaten Polewali Mandar" ini menggunakan dua variabel independen (bebas) dan satu variabel dependen (terikat). Dua variabel independen (bebas) tersebut yaitu minat baca (X1) dan kontinuitas belajar (X2). Sedangkan variabel dependen (terikat) adalah hasil belajar Sejarah Kebudayaan Islam siswa $(\mathrm{Y})$.

Sampel yang diambil datanya dalam penelitian ini adalah siswa kelas VIII MTs. DDI Cabang Mapilli Kecamatan Mapilli Kabupaten Polewali Mandar yang berjumlah 24 siswa. Deskripsi data dari variabel minat baca (X1) dan kontinuitas belajar (X2) didasarkan pada hasil angket yang diberikan pada 24 siswa kelas VIII MTs. DDI Cabang Mapilli Kecamatan Mapilli Kabupaten Polewali Mandar. Sementara itu, data hasil belajar Sejarah Kebudayaan Islam siswa (Y) dilihat dari nilai yang terdapat dalam dokumen hasil tes Sejarah Kebudayaan Islam pada siswa yang dimiliki guru kelas VIII MTs. DDI Cabang Mapilli. Deskripsi data yang disajikan dari hasil penelitian ini adalah untuk memberikan gambaran secara umum mengenai persebaran data yang diperoleh di lapangan. Data yang disajikan berupa data mentah yang diolah dengan menggunakan teknik statistik deskripsi dengan menggunakan bantuan program SPSS (Statistical Product and Service Solution) versi 20.0 for windows.

Berdasarkan dokumentasi data yang diperoleh penulis, hasil belajar Sejarah Kebudayaan Islam yang diraih siswa kelas VIII MTs. DDI Cabang Mapilli Kecamatan Mapilli Kabupaten Polewali Mandar tergolong baik. Tidak ada siswa yang memperoleh nilai di bawah KKM (Kriteria Ketuntasan Minimal) apalagi sampai tinggal kelas.

Berdasarkan hasil pengamatan yang dilakukan penulis, minat membaca siswa terhadap bukubuku ataupun juga bahan pembelajaran tergolong rendah. Hal ini dapat dilihat dari kurangnya aktifitas membaca yang dilakukan siswa baik di dalam kelas ataupun juga di luar kelas. Terhitung hanya beberapa siswa saja yang terkadang meluangkan waktu istirahatnya untuk membaca. Ruang perpustakaan yang ada juga sangat jarang dikunjungi oleh siswa. Siswa baru membaca ataupun juga meminjam buku di perpustakaan jika diberikan tugas oleh gurunya.

Sedikit berbeda dengan aktifitas membaca siswa, aktifitas belajar siswa cenderung lebih terlaksana dengan baik. Dalam aktifitas belajarnya, siswa terlihat lebih tekun belajar baik secara individu maupun kelompok. Dalam aktifitas pembelajaran di kelas, semua siswa dapat mengikuti 
kegiatan pembelajaran dengan baik. Perhatian siswa terhadap materi pembelajaran pun memberikan keleluasaan bagi guru sebagai fasilitator untuk membantu siswa dalam memahami materi pelajaran.

Data yang diamati dalam penelitian ini adalah data yang terkait dengan indikator-indikator yang terdapat pada variabel-variabel penelitian. Indikator-indikator variabel minat baca (X1) yang dijadikan acuan dalam penelitian ini adalah: (1) kebutuhan terhadap bacaan, (2) tindakan untuk mencari bacaan, (3) rasa senang terhadap bacaan, (4) keinginan untuk selalu membaca, dan (5) tindak lanjut (menindaklanjuti dari apa yang dibaca). Sedangkan indikator-indikator variabel kontinuitas belajar (X2) antara lain: (1) keteraturan, (2) kedisiplinan, (3) ketekunan, (4) pengaturan waktu, dan (5) pemusatan perhatian pada materi pelajaran.

Sebelum angket digunakan sebagai instrumen penelitian, terlebih dahulu dilakukan try out kepada 24 orang responden di luar sampel. Try out digunakan untuk mengetahui butir-butir soal yang memenuhi syarat validitas dan reliabilitas angket sebagai instrumen penelitian. Dari 20 butir soal yang diujikan, hanya 14 butir soal yang dinyatakan valid dan reliabel dan selanjutnya diujikan sebagai instrumen penelitian. Variabel minat membaca terwakili oleh 7 butir soal dan variabel kontinuitas belajar juga terwakili oleh 7 butir soal.

Pendeskripsian data dalam penelitian ini juga diberlakukan pada jawaban dari angket mengenai minat membaca (X1) dan kontinuitas belajar (X2) siswa yang dikorelasikan dengan hasil belajar Sejarah Kebudayaan Islam siswa (Y) untuk menentukan pengaruh minat membaca (X1) dan kontinuitas belajar (X2) siswa terhadap hasil belajar Sejarah Kebudayaan Islam siswa (Y). Berdasarkan data hasil penelitian melalui penyebaran angket kepada siswa, maka deskripsi data variabel minat baca (X1), variabel kontinuitas belajar (X2) dan variabel hasil belajar Sejarah Kebudayaan Islam siswa (Y), diperoleh hasil sebagai berikut:

\section{Data Hasil Belajar Sejarah Kebudayaan Islam (Y)}

Data dari hasil penelitian mengenai variabel hasil belajar Sejarah Kebudayaan Islam (Y) yang diperoleh siswa kelas VIII MTs. DDI Cabang Mapilli Kecamatan Mapilli Kabupaten Polewali Mandar dapat dilihat pada tabel 2.

Berdasarkan pengolahan data statistik hasil penelitian yang terdapat dalam tabel 2, dapat diketahui bahwa jumlah responden dalam penelitian ini adalah sebanyak 24 siswa. Dari tabel 2 pula, diperoleh nilai rata-rata (mean) 71,96, nilai tengah (median) 71,5, modus (mode) 70, simpangan baku (standart deviation) 4,278, variansi (variance) 18,303, skor terendah (minimum) 65, dan skor maksimal (maximum) 79. Skor total untuk variabel hasil belajar Sejarah Kebudayaan Islam (Y) yang diperoleh siswa kelas VIII MTs. DDI Cabang Mapilli Kecamatan Mapilli Kabupaten Polewali Mandar adalah 1.727 yang dapat dilihat pada tabel 3 .

Tabel 2.

Statistik Data Hasil Belajar Sejarah Kebudayaan Islam pada Siswa Kelas VIII MTs. DDI Cabang Mapilli

\begin{tabular}{|c|c|c|}
\hline $\mathrm{N} \quad$ Valid & 24 \\
& Missing & 0 \\
& Mean & 71.96 \\
& Median & \\
\hline
\end{tabular}




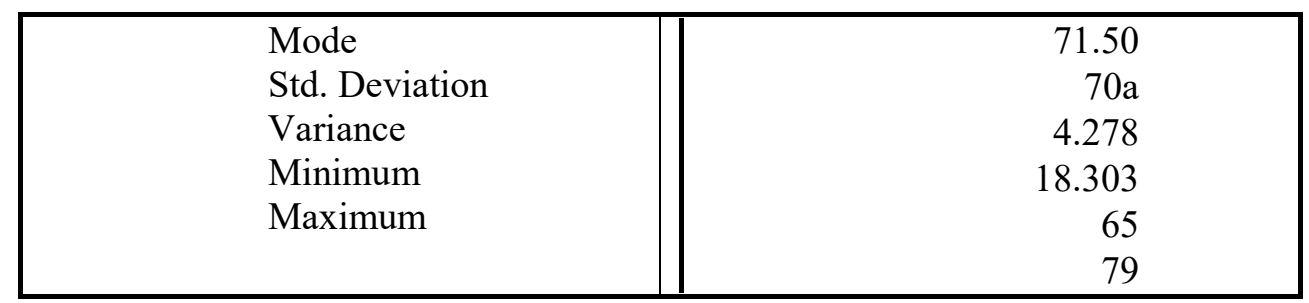

Sumber: Hasil Out Put SPSS

Data tentang nilai hasil belajar Sejarah Kebudayaan Islam (Y) yang diperoleh siswa kelas VIII MTs. DDI Cabang Mapilli Kecamatan Mapilli Kabupaten Polewali Mandar dapat dilihat pada tabel 3 .

Tabel 3.

Nilai Hasil Belajar Sejarah Kebudayaan Islam yang Dicapai Siswa

Kelas VIII MTs. DDI Cabang Mapilli

\begin{tabular}{|c|c|c|c|}
\hline No & $\begin{array}{c}\text { Nilai Sejarah Kebudayaan } \\
\text { Islam }\end{array}$ & No & $\begin{array}{c}\text { Nilai Sejarah Kebudayaan } \\
\text { Islam }\end{array}$ \\
\hline 1. & 70 & 13. & 68 \\
2. & 69 & 14. & 78 \\
3. & 65 & 15. & 70 \\
4. & 73 & 16. & 73 \\
5. & 72 & 17. & 66 \\
6. & 73 & 18. & 79 \\
7. & 70 & 19. & 76 \\
8. & 78 & 20. & 75 \\
9. & 66 & 22. & 71 \\
10. & 79 & 23. & 77 \\
11. & 69 & 24. & 67 \\
12. & 70 & & 73 \\
\hline \multicolumn{2}{|c|}{ Jumlah } \\
\hline
\end{tabular}

Sumber: Dokumen Hasil Tes Sejarah Kebudayaan Islam

\section{Data Minat Baca (X1)}

Data hasil penelitian mengenai variabel minat baca (X1) yang dimiliki siswa kelas VIII MTs. DDI Cabang Mapilli Kecamatan Mapilli Kabupaten Polewali Mandar diperoleh melalui penyebaran angket. Dari 7 butir instrumen dengan skala pilihan jawaban empat (4 alternatif jawaban), mempunyai skor antara 7 sampai 28. Data mengenai variabel minat baca (X1) yang dimiliki siswa kelas VIII MTs. DDI Cabang Mapilli tersebut dapat dilihat pada tabel 4.

Berdasarkan pengolahan data statistik hasil penelitian yang terdapat dalam tabel 4, diperoleh nilai rata-rata (mean) 21,75, nilai tengah (median) 22, modus (mode) 24, simpangan baku (standart deviation) 2,723, variansi (variance) 7,413, skor terendah (minimum) 16, dan skor maksimal (maximum) 27. Skor total untuk variabel minat baca (X1) yang dimiliki siswa kelas VIII MTs. DDI Cabang Mapilli Kecamatan Mapilli Kabupaten Polewali Mandar adalah 522 yang dapat dilihat pada tabel 5 .

Tabel 4.

Statistik Data Minat Baca Siswa Kelas VIII MTs. DDI Cabang Mapilli 


\begin{tabular}{|l||r|}
\hline $\mathrm{N} \quad$ Valid & 24 \\
Missing & 0 \\
Mean & \\
Median & 21.75 \\
Mode & 22.00 \\
Std. Deviation & 24 \\
Variance & 2.723 \\
Minimum & 7.413 \\
Maximum & 16 \\
& 27 \\
\hline
\end{tabular}

Sumber: Hasil Out Put SPSS

Data tentang nilai variabel minat baca (X1) yang dimiliki siswa kelas VIII MTs. DDI Cabang Mapilli Kecamatan Mapilli Kabupaten Polewali Mandar dapat dilihat pada tabel 5 berikut ini:

Tabel 5.

Nilai Minat Baca Siswa Kelas VIII MTs. DDI Cabang Mapilli

\begin{tabular}{|c|c|c|c|}
\hline No & Nilai Minat Baca & No & Nilai Minat Baca \\
\hline 1. & 16 & 13. & 21 \\
\hline 2. & 19 & 14. & 22 \\
\hline 3. & 24 & 15. & 24 \\
\hline 4. & 24 & 16. & 22 \\
\hline 5. & 24 & 17. & 27 \\
\hline 6. & 19 & 18. & 23 \\
\hline 7. & 20 & 19. & 18 \\
\hline 8. & 22 & 20. & 24 \\
\hline 9. & 21 & 21. & 20 \\
\hline 10. & 23 & 22. & 23 \\
\hline 11. & 24 & 23. & 16 \\
\hline 12. & 22 & 24. & 24 \\
\hline \multicolumn{2}{|c|}{ Jumlah } & $\mathbf{5 2 2}$ \\
\hline
\end{tabular}

Sumber: Hasil Angket Minat Baca

\section{Data Kontinuitas Belajar (X2)}

Data hasil penelitian mengenai variabel kontinuitas belajar (X2) yang dilakukan siswa kelas VIII MTs. DDI Cabang Mapilli Kecamatan Mapilli Kabupaten Polewali Mandar diperoleh melalui penyebaran angket. Dari 7 butir instrumen dengan skala pilihan jawaban empat (4 alternatif jawaban), mempunyai skor antara 7 sampai 28. Data variabel kontinuitas belajar (X2) yang dilakukan siswa kelas VIII MTs. DDI Cabang Mapilli tersebut dapat dilihat pada tabel 6.

Berdasarkan pengolahan data statistik hasil penelitian yang terdapat dalam tabel 6 , diperoleh nilai rata-rata (mean) 23,25, nilai tengah (median) 23,5, modus (mode) 25, simpangan baku (standart deviation) 1,622, variansi (variance) 2,63, skor terendah (minimum) 19, dan skor maksimal (maximum) 25. Skor total untuk variabel kontinuitas belajar (X2) yang dilakukan siswa kelas VIII MTs. DDI Cabang Mapilli Kecamatan Mapilli Kabupaten Polewali Mandar adalah 558 yang dapat dilihat pada tabel 7.

Tabel 6. 
Statistik Data Kontinuitas Belajar Siswa Kelas VIII MTs. DDI Cabang Mapilli

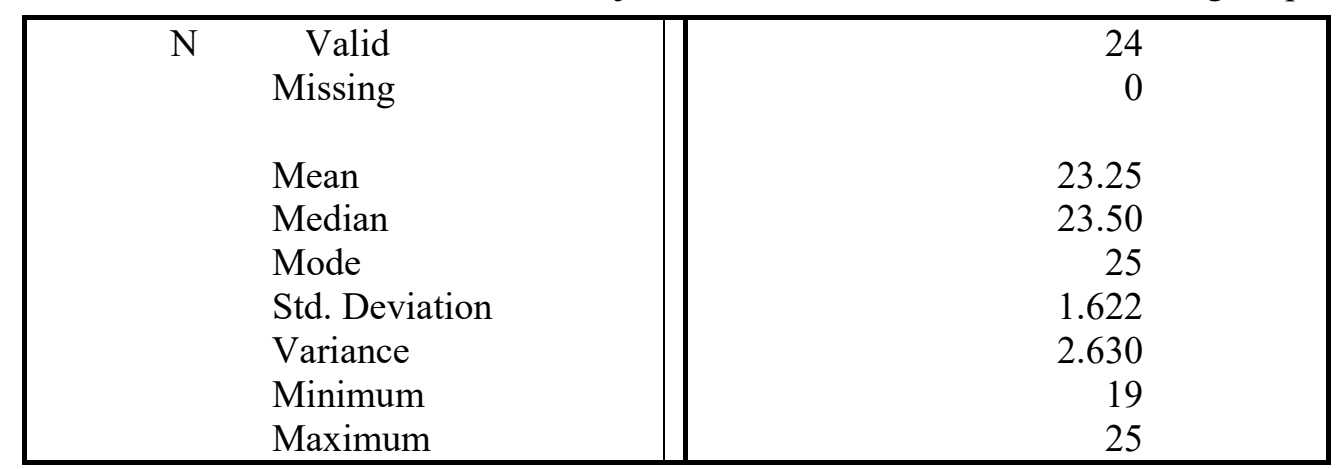

Sumber: Hasil Out Put SPSS

Data tentang nilai variabel kontinuitas belajar (X2) yang dilakukan siswa kelas VIII MTs. DDI Cabang Mapilli Kecamatan Mapilli Kabupaten Polewali Mandar dapat dilihat pada tabel 7 berikut ini:

Tabel 7.

Nilai Kontinuitas Belajar Siswa Kelas VIII MTs. DDI Cabang Mapilli

\begin{tabular}{|c|c|c|c|}
\hline No & Nilai Kontinuitas Belajar & No & Nilai Kontinuitas Belajar \\
\hline 1. & 22 & 13. & 23 \\
\hline 2. & 23 & 14. & 23 \\
\hline 3. & 25 & 15. & 25 \\
\hline 4. & 24 & 16. & 25 \\
\hline 5. & 25 & 17. & 25 \\
\hline 6. & 24 & 18. & 25 \\
\hline 7. & 22 & 19. & 21 \\
\hline 8. & 24 & 20. & 25 \\
\hline 9. & 22 & 21. & 22 \\
\hline 10. & 23 & 22. & 24 \\
\hline 11. & 22 & 23. & 19 \\
\hline 12. & 21 & 24. & 24 \\
\hline & Jumlah & & $\mathbf{5 5 8}$ \\
\hline
\end{tabular}

Sumber: Hasil Angket dan Observasi Kontinuitas Belajar Siswa

\section{B. Analisis dan Pembahasan}

\section{Uji Normalitas}

Uji normalitas digunakan untuk mengetahui apakah data yang akan dianalisis berdistribusi normal atau tidak. Hasil uji normalitas dalam penelitian ini bisa dilihat dalam tabel 8 .

Berdasarkan data dalam tabel 8 diperoleh nilai signifikansi unstandardized residual pada kolom Kolmogorof-Smirnov sebesar 0,200 dan nilai signifikansi unstandardized residual pada kolom Shapiro-Wilk sebesar 0,552. Berdasarkan perhitungan data yang diperoleh, dapat diketahui bahwa nilai signifikansi unstandardized residual lebih besar dari 0,05. Maka dapat disimpulkan bahwa datadata hasil penelitian ini, yaitu data minat membaca (X1), data kontinuitas belajar (X2) dan data hasil belajar Sejarah Kebudayaan Islam (Y) adalah berdistribusi normal. 
Tabel 8.

Hasil Uji Normalitas Sebaran Data

\begin{tabular}{|c|c|c|c|c|c|c|}
\hline \multicolumn{7}{|c|}{ Normalitas } \\
\hline & \multicolumn{3}{|c|}{ Kolmogorov-Smirnov $^{\mathrm{a}}$} & \multicolumn{3}{|c|}{ Shapiro-Wilk } \\
\hline & Statistic & $d f$ & Sig. & Statistic & $d f$ & Sig. \\
\hline $\begin{array}{l}\text { Unstandardized } \\
\text { Residual }\end{array}$ & .121 & 24 & $.200^{*}$ & .965 & 24 & .552 \\
\hline
\end{tabular}

Sumber: Hasil Out Put SPSS

\section{Analisis Regresi Ganda}

Setelah dilakukan pengolahan data hasil penelitian dengan menggunakan program SPSS (Statistical Product and Service Solution) versi 20.0 for windos, diperoleh nilai koefisien regresi yang dapat dilihat pada tabel 9 sebagai berikut:

Tabel 9

Koefisien Regresi

\begin{tabular}{|c|c|c|c|c|c|}
\hline \multicolumn{6}{|c|}{ Koefisien } \\
\hline & \multicolumn{2}{|c|}{$\begin{array}{c}\text { Unstandardized } \\
\text { Coefficients }\end{array}$} & $\begin{array}{l}\text { Standardized } \\
\text { Coefficients }\end{array}$ & \multirow[b]{2}{*}{$T$} & \multirow[b]{2}{*}{ Sig. } \\
\hline Model & $B$ & Std. Error & Beta & & \\
\hline 1 (Constant) & 56.515 & 13.299 & & 4.250 & .000 \\
\hline Minat baca & .247 & .474 & .157 & .522 & .607 \\
\hline $\begin{array}{l}\text { Kontinuitas } \\
\text { belajar }\end{array}$ & .896 & .795 & .340 & 1.126 & .273 \\
\hline
\end{tabular}

Sumber: Hasil Out Put SPSS

Berdasarkan data pada tabel 9 diperoleh data-data yang dapat diuraikan sebagai berikut:

a. Nilai konstanta $=56,515$

b. Koefisien regresi variabel minat baca $=0,157$

c. Koefisien regresi variabel kontinuitas belajar $=0,340$

Berdasarkan hasil perhitungan koefisien regresi tersebut, persamaan regresi yang diperoleh adalah sebagai berikut:

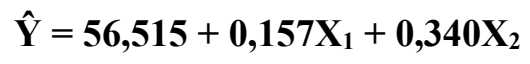

Keterangan:

$\hat{\mathrm{Y}}=$ Hasil Belajar Sejarah Kebudayaan Islam

$\mathrm{X}_{1}=$ Minat Baca

$\mathrm{X}_{2}=$ Kontinuitas Belajar

Interpretasi persamaan regresi tersebut dapat dijelaskan sebagai berikut:

a. Konstanta sebesar 56,515. Artinya adalah jika nilai dari variabel minat baca (X1) dan kontinuitas belajar (X2) sama dengan nol, maka nilai hasil belajar Sejarah Kebudayaan Islam (Y) yang diperoleh siswa kelas VIII MTs. DDI Cabang Mapilli Kecamatan Mapilli Kabupaten Polewali Mandar adalah 56,515. Dalam penelitian ini, nilai variabel minat baca (X1) dan kontinuitas belajar (X2) tidak mungkin sama dengan nol serta nilai Y tidak mungkin negatif. 
b. Koefisien regresi variabel minat baca (X1) sebesar 0,157. Artinya, jika nilai variabel minat baca (X1) mengalami kenaikan sebesar 1 satuan, maka nilai hasil belajar Sejarah Kebudayaan Islam (Y) yang diperoleh siswa kelas VIII MTs. DDI Cabang Mapilli Kecamatan Mapilli Kabupaten Polewali Mandar akan mengalami peningkatan nilai sebesar 0,157 satuan dengan asumsi nilai variabel kontinuitas belajar (X2) adalah tetap. Berdasarkan hasil perhitungan yang terdapat pada tabel 9 diketahui bahwa koefisien regresi variabel minat baca (X1) bernilai positif, artinya terjadi pengaruh positif dari variabel minat baca (X1) terhadap hasil belajar Sejarah Kebudayaan Islam (Y) yang diperoleh siswa kelas VIII MTs. DDI Cabang Mapilli Kecamatan Mapilli Kabupaten Polewali Mandar. Dapat disimpulkan pula bahwa semakin naik nilai variabel minat baca (X1), maka semakin naik nilai variabel hasil belajar Sejarah Kebudayaan Islam (Y).

c. Koefisien regresi variabel kontinuitas belajar (X2) sebesar 0,340. Artinya, jika nilai variabel kontinuitas belajar (X2) mengalami kenaikan sebesar 1 satuan, maka nilai hasil belajar Sejarah Kebudayaan Islam (Y) yang diperoleh siswa kelas VIII MTs. DDI Cabang Mapilli Kecamatan Mapilli Kabupaten Polewali Mandar akan mengalami kenaikan nilai sebesar 0,340 satuan dengan asumsi nilai variabel minat baca (X1) adalah tetap. Berdasarkan hasil perhitungan yang terdapat pada tabel 9 diketahui bahwa koefisien regresi variabel kontinuitas belajar (X2) bernilai positif, artinya terjadi pengaruh positif dari variabel kontinuitas belajar (X2) terhadap hasil belajar Sejarah Kebudayaan Islam (Y) yang diperoleh siswa kelas VIII MTs. DDI Cabang Mapilli Kecamatan Mapilli Kabupaten Polewali Mandar. Dapat disimpulkan pula bahwa semakin naik nilai variabel kontinuitas belajar (X2), maka semakin naik pula nilai variabel hasil belajar Sejarah Kebudayaan Islam (Y) yang diperoleh siswa kelas VIII MTs. DDI Cabang Mapilli Kecamatan Mapilli Kabupaten Polewali Mandar.

\section{Uji F}

Uji koefisien regresi secara bersama-sama (Uji F) digunakan untuk menguji pengaruh variabel independen secara bersama-sama terhadap variabel dependen. Uji F dari hasil pengolahan data dalam penelitian ini dapat dilihat pada tabel 10 berikut ini:

Tabel 10.

Hasil Uji F (ANOVA)

\begin{tabular}{|rr|r|r|r|r|r|}
\hline \multicolumn{7}{|c|}{ ANOVA } \\
\hline Model & $\begin{array}{c}\text { Sum of } \\
\text { Squares }\end{array}$ & \multicolumn{1}{c|}{ df } & $\begin{array}{c}\text { Mean } \\
\text { Square }\end{array}$ & F & \multicolumn{1}{c|}{ Sig. } \\
\hline 1 & Regression & 26.839 & 2 & 13.420 & 7.155 & $.026^{\mathrm{a}}$ \\
\hline \multicolumn{2}{|c|}{ Residual } & 394.119 & 21 & 18.768 & & \\
\hline \multicolumn{2}{|c|}{ Total } & 420.958 & 23 & & & \\
\hline
\end{tabular}

Sumber: Hasil Out Put SPSS

Berdasarkan data pada tabel 10 dapat dilihat bahwa nilai signifikansi regresi sebesar 0,026 . Jika melihat nilai signifikansi yang diperoleh, maka dapat disimpulkan bahwa nilai signifikansi regresi lebih kecil dari 0,05. Berdasarkan hasil perhitungan tersebut, dapat disimpulkan bahwa ada pengaruh secara bersama-sama yang signifikan dari minat baca dan kontinuitas belajar terhadap hasil belajar Sejarah Kebudayaan Islam yang diperoleh siswa kelas VIII MTs. DDI Cabang Mapilli 
Kecamatan Mapilli Kabupaten Polewali Mandar. Berdasarkan tabel 10 diperoleh nilai F hitung antara variabel minat baca (X1) dan kontinuitas belajar (X2) terhadap variabel hasil belajar Sejarah Kebudayaan Islam (Y) adalah, 7,155. Sedangkan nilai $F$ tabel untuk $\mathrm{df}_{1}=2$ dan $\mathrm{df}_{2}=21$ adalah 3,467. Apabila dibandingkan, maka didapatkan kesimpulan bahwa $\mathrm{F}$ hitung $>\mathrm{F}$ tabel, yakni 7,155 > 3,467. Oleh karena itu, maka $\mathrm{H}_{0}$ (tidak ada pengaruh) ditolak dan $\mathrm{H}_{1}$ (ada pengaruh) diterima, sehingga dapat dijelaskan bahwa ada pengaruh yang signifikan dari minat baca dan kontinuitas belajar terhadap hasil belajar Sejarah Kebudayaan Islam yang diperoleh siswa kelas VIII MTs. DDI Cabang Mapilli Kecamatan Mapilli Kabupaten Polewali Mandar.

\section{Analisis Koefisien Determinasi}

Analisis $\mathrm{R}^{2}$ (R kuadrat/R Square) atau koefisien determinasi digunakan untuk mengetahui seberapa besar prosentase sumbangan pengaruh variabel independen secara bersama-sama terhadap variabel dependen. Analisis koefisien determinasi $\left(\mathrm{R}^{2}\right)$ dari hasil pengolahan data dengan program SPSS (Statistical Product and Service Solution) versi 20 dalam penelitian ini dapat dilihat pada tabel 11 berikut ini:

Tabel 11.

Model Summary

\begin{tabular}{|l|c|r|r|r|}
\hline \multicolumn{5}{|c|}{ Model Summary } \\
\hline Model & $\mathrm{R}$ & $\mathrm{R}$ Square & $\begin{array}{c}\text { Adjusted } \\
\text { R Square }\end{array}$ & $\begin{array}{c}\text { Std. Error of the } \\
\text { Estimate }\end{array}$ \\
\hline 1 & $.603^{\mathrm{a}}$ & .364 & .025 & 4.332 \\
\hline
\end{tabular}

Sumber: Hasil Out Put SPSS

Berdasarkan data hasil perhitungan yang terdapat pada tabel 11, diperoleh angka R Square sebesar 0,364. Mengacu pada hasil perhitungan tersebut, dapat diartikan bahwa 36,4\% hasil belajar Sejarah Kebudayaan Islam yang diperoleh siswa kelas VIII MTs. DDI Cabang Mapilli Kecamatan Mapilli Kabupaten Polewali Mandar dipengaruhi oleh kedua variabel independen (minat baca dan kontinuitas belajar). Sedangkan sisanya $(100 \%-36,4 \%=63,6 \%)$ sebesar 63,6\% dipengaruhi oleh variabel lain yang tidak dikaji dalam penelitian ini.

Penarikan kesimpulan dalam penelitian ini dipengaruhi oleh penentuan sampel dan juga dipengaruhi perhitungan data pada variabel yang diteliti atau variabel lainnya, sehingga pengaruh variabel minat baca dan kontinuitas belajar terhadap hasil belajar Sejarah Kebudayaan Islam yang diperoleh siswa yang pada saat pengujian hipotesis ikut berperan. Menurut Arikunto, perumusan hipotesis dilakukan secara hati-hati setelah peneliti memperoleh bahan yang lengkap berdasarkan landasan teori yang kuat. Namun, rumusan hipotesis tidak selamanya benar. Benar dan tidaknya hipotesis tidak ada hubungannya dengan terbukti atau tidaknya hipotesis tersebut. ${ }^{17}$ Kemungkinan seorang peneliti merumuskan hipotesis yang isinya benar, tetapi setelah data terkumpul dan dianalisis ternyata bahwa hipotesis tersebut ditolak atau tidak terbukti. Namun dalam penelitian ini, isi rumusan hipotesis penelitian sudah benar dan setelah dianalisis, hipotesis yang dirumuskan tersebut juga diterima atau terbukti.

\footnotetext{
${ }^{17}$ Suharsimi Arikunto Prosedur Penelitian Suatu Pendekatan Prkatik (Jakarta: Rineka Cipta, 2013), h. 75.
} 
Hasil belajar yang diperoleh siswa di sekolahnya bersifat relatif, artinya dapat berubah setiap saat. Hal ini terjadi karena hasil belajar siswa sangat berhubungan erat dengan faktor-faktor yang mempengaruhinya. Faktor-faktor tersebut saling berkaitan antara satu faktor dengan faktor yang lainnya.

\section{PENUTUP}

\section{A. Simpulan}

Berdasarkan pada hasil penelitian dan pembahasan hasil analisis statistik data, dapat disimpulkan hal-hal sebagai berikut:

1. Minat baca yang dimiliki siswa kelas VIII MTs. DDI Cabang Mapilli Kecamatan Mapilli Kabupaten Polewali Mandar adalah tergolong rendah dengan nilai rata-rata (mean) sebesar 21,75. Hal ini dilihat dari kurangnya aktifitas membaca yang dilakukan siswa baik di dalam kelas ataupun juga di luar kelas. Hanya beberapa siswa saja yang terkadang meluangkan waktu istirahatnya untuk membaca. Ruang perpustakaan yang ada juga sangat jarang dikunjungi oleh siswa. Siswa baru membaca ataupun juga meminjam buku di perpustakaan jika diberikan tugas oleh gurunya.

2. Kontinuitas belajar Sejarah Kebudayaan Islam pada siswa kelas VIII MTs. DDI Cabang Mapilli Kecamatan Mapilli Kabupaten Polewali Mandar sudah terlaksana dengan baik dengan nilai rata-rata (mean) sebesar 23,25. Dalam aktifitas belajarnya, siswa terlihat lebih tekun belajar baik secara individu maupun kelompok. Dalam aktifitas pembelajaran di kelas, semua siswa dapat mengikuti kegiatan pembelajaran dengan baik.

3. Ada pengaruh yang signifikan dari minat baca dan kontinuitas belajar terhadap hasil belajar Sejarah Kebudayaan Islam yang diperoleh siswa kelas VIII MTs. DDI Cabang Mapilli Kecamatan Mapilli Kabupaten Polewali Mandar. Variabel minat baca (X1) dan kontinuitas belajar (X2) secara bersama-sama hanya berpengaruh sebesar 36,4\% terhadap variabel hasil belajar Sejarah Kebudayaan Islam (Y). Sedangkan sisanya sebesar 63,6\% dipengaruhi oleh variabel-variabel lain yang tidak dikaji dalam penelitian ini.

\section{B. Saran}

Berdasarkan hasil yang diperoleh dari penelitian, maka saran-saran yang dapat peneliti sampaikan adalah:

1. Minat membaca pada siswa/anak perlu ditanamkan dan ditumbuhkan sejak dini sehingga kebiasaan membaca pada siswa/anak dapat berlangsung sepanjang hayat.

2. Sebaiknya orang tua perlu untuk menanamkan kesadaran pada anak akan pentingnya membaca di rumah dan guru juga dapat berfungsi sebagai motivator terhadap aktifitas membaca pada siswa di sekolah.

3. Guru sebaiknya dapat menciptakan suasana/kondisi belajar yang dapat memotivasi siswa untuk belajar, dengan kata lain perlu strategi dalam pembelajaran yang dapat meningkatkan minat dan aktifitas belajar siswa. 
4. Diharapkan orang tua dan guru dapat bertugas sebagai pembimbing dalam aktifitas belajar siswa sehingga siswa melaksanakan aktifitas belajarnya secara rutin dan teratur untuk memperoleh nilai hasil belajar yang optimal.

\section{DAFTAR PUSTAKA}

Anni, Catharina. Psikologi Belajar. Semarang: UNNES Press 2014.

Apriyati, Tri, Joharman, dan Harun Setyo Budi. Pengaruh Perhatian Orang Tua dan Minat Membaca terhadap Hasil Belajar Bahasa Indonesia. Jurnal Kalam Cendekia PGSD Kebumen, Volume 1, Nomor 4, 2013.

Arikunto, Suharsimi. Prosedur Penelitian Suatu Pendekatan Prkatik. Jakarta: Rineka Cipta, 2013.

BSNP. Standar Isi untuk Satuan Pendidikan Dasar dan Menengah. Jakarta: BSNP, 2006.

Dalman. Keterampilan Membaca. Jakarta: Rajawali Pers, 2014.

Fauziyah, Risqi. Faktor-Faktor yang Mempengaruhi Minat Mahasiswa PGSD UPP Tegal Untuk Membaca Buku di Perpustakaan PGSD UPP Tegal. Laporan Penelitian Institusional, Semarang: Universitas Negeri Semarang, 2013.

Ghozali, Imam. Aplikasi Analisis Multivariate dengan Program SPSS. Semarang: B-P UNDIP, 2011.

Harjanto, Bob. Merangsang dan Melejitkan Minat Baca Anak Anda. Yogyakarta: Manika Books, 2011.

Mikarsa, Hera Lestari. Pendidikan Anak di SD dan SMP. Cetakan ke XV, Jakarta: Universitas Terbuka, 2013.

Mulyani, Nanik. Motivasi Berprestasi, Kontinuitas Belajar dan Prestasi Belajar. Yogyakarta: Aura Pustaka, 2014.

Musfiroh, Takdiroatun. Menumbuhkembangkan Baca-Tulis Anak. Jakarta: Grasindo, 2014.

Naim, Ngainun. The Power of Reading. Yogyakarta: Aura Pustaka, 2013.

Nursalina, Ade Irma dan Tri Esti Budiningsih. Hubungan Motivasi Berprestasi dengan Minat Membaca pada Anak. Jurnal Bahasa, Sastra dan Pembelajaran, Volume 2, Nomor 1, 2014.

Purwanto. Evaluasi Hasil Belajar. Yogyakarta: Pustaka Pelajar, 2014.

Republik Indonesia. Peraturan Menteri Pendidikan Nasional Republik Indonesia No. 23 Tahun 2006 tentang Standar Kompetensi Lulusan untuk Satuan Pendidikan Dasar dan Menengah. Jakarta: Pemerintah RI, 2006.

Republik Indonesia. Peraturan Pemerintah Republik Indonesia No. 47 Tahun 2008 tentang Wajib Belajar. Jakarta: Pemerintah RI, 2008.

Republik Indonesia. Peraturan Menteri Pendidikan dan Kebudayaan Republik Indonesia No. 104 Tahun 2014 tentang Penilaian Hasil Belajar oleh Pendidik pada Pendidikan Dasar dan Pendidikan Menengah. Jakarta: Pemerintah RI, 2014.

Siregar, Syofian P. Statistik Deskriptif Untuk Penelitian. Jakarta: Raja Grafindo Persada, 2010.

Slameto. Belajar dan Faktor-faktor yang Mempengaruhinya. Jakarta: Rineka Cipta, 2013.

Sudarsana Undang dan Bastiano. Pembinaan Minat Baca. Jakarta: Universitas Terbuka, 2012.

Sudjana, Nana. Penilaian Hasil Proses Belajar Mengajar. Cetakan ke XV, Bandung: Remaja Rosdakarya, 2013. 
Sugiyono. Metode Penelitian Pendekatan Kuantitatif, Kualitatif, dan R \& D. Bandung: Alfabeta, 2015.

Sukardi, Ismail. Model-model Pembelajaran Moderen: Bekal untuk Guru Profesional. Yogyakarta: Tunas Gemilang Press, 2013.

Sukmadinata, Nana Syaodih. Metode Peneltian Pendidikan. Bandung: Remaja Rosdakarya, 2012.

Suprijono, Agus. Cooperative Learning, Teori dan Aplikasi PAIKEM. Yogyakarta: Pustaka Pelajar, 2012.

Susanto, Ahmad. Teori Belajar dan Pembelajaran di Sekolah Dasar Jakarta: Prenadamedia Group, 2013.

Tarigan, Henry Guntur. Membaca sebagai Suatu Keterampilan Berbahasa. Bandung: Angkasa, 2015.

Yusri. Statistika Sosial : Aplikasi dan Interpretasi. Yogyakarta: Graha Ilmu, 2009. 